Syntax Literate: Jurnal Ilmiah Indonesia p-ISSN: 2541-0849

e-ISSN: 2548-1398

Vol. 7, No. 1, Januari 2022

\title{
EFEKTIFITAS TINDAK LANJUT REKOMENDASI HASIL PEMERIKSAAN
}

\author{
Damas Ali Wijaya, Retno Sunu Astuti, Budi Puspo Priyadi \\ Universitas Diponegoro (UNDIP) Semarang, Indonesia \\ Email:damasjayz@gmail.com, retnosunu@gmail.com, budipuspo@yahoo.com
}

\begin{abstract}
Abstrak
Badan Pemeriksa Keuangan (BPK) Perwakilan Provinsi Jawa Tengah melaksanakan tugas pemeriksaan atas pengelolaan dan tanggung jawab keuangan daerah pada Pemerintah Kabupaten Wonosobo. Status tindak lanjut rekomendasi hasil pemeriksaan tersebut masih ada yang belum selesai tindaklanjutnya, ada yang belum ditindaklanjuti dan tidak dapat ditindaklanjuti. Terkait dengan hal tersebut penelitian ini bertujuan untuk menganalisis efektifitas pemerintah daerah dalam melaksanakan tindak lanjut atas rekomendasi hasil pemeriksaan, dan apa yang menjadi faktor-faktor penghambat dan pendukung dalam menindaklanjuti rekomendasi hasil pemeriksaan. Penelitian ini dilakukan dengan pendekatan kualitatif, analisis data sekunder, observasi dan wawancara dengan informan yang dipilih yaitu pejabat teknis di Inspektorat, BPPKAD, pejabat dan auditor di BPK yang menangani pemantauan tindak lanjut. Hasil penelitian menunjukkan bahwa fungsi kepatuhan terhadap peraturan perundang-undangan dalam pemantauan belum berjalan sebagaimana mestinya, masih terjadinya permasalahan serupa di tahun berikutnya menunjukkan tindak lanjut rekomendasi hasil pemeriksaan belum sepenuhnya efektif, namun tindakan perbaikan sesuai rekomendasi telah efektif dalam memperoleh opini WTP.
\end{abstract}

Kata Kunci: pemeriksaan; rekomendasi; tindaklanjut

\section{Abstract}

The Audit Board (BPK) representative of Central Java Province carries out the task of examination of the management and financial responsibility of the region at the Wonosobo Regency Government. The status of follow-up recommendations of the examination result is still there that has not been completed follow-up, some that have not been followed up and cannot be followed up. Related to this, this study aims to analyze the effectiveness of local governments in carrying out followup on the recommendations of examination results, and what are the inhibiting and supporting factors in following up on the recommendations of examination results. This research was conducted with qualitative approach, secondary data analysis, observation and interview with selected informants, namely technical officials in the Inspectorate, BPPKAD, officials and auditors in the CPC who handle follow-up monitoring. The results showed that the function of compliance with the laws and regulations in monitoring has not worked as it should, still the occurrence of similar problems in the following year shows the follow-up recommendations of the

$\begin{array}{ll}\text { How to cite: } & \text { Wijaya. D.A., Retno Sunu Astuti \& Budi Puspo Priyadi (2022) Efektifitas Tindak Lanjut Rekomendasi Hasil } \\ & \text { Pemeriksaan. Syntax Literate: Jurnal Ilmiah Indonesia, 7(1). http://dx.doi.org/10.36418/Syntax- } \\ & \text { Literate.v7i1.5650 } \\ \text { E-ISSN: } & 2548-1398 \\ \text { Published by: } & \text { Ridwan Institute }\end{array}$


examination results have not been fully effective, but remedial action according to the recommendations has been effective in obtaining WTP opinions.

Keywords: checks; recommendations; follow-ups

Received: 2021-12-20; Accepted: 2022-01-05; Published: 2022-01-15

\section{Pendahuluan}

Berdasarkan amanat UUD 1945 dan salah satu aturan pelaksananya yaitu UU Nomor 15 Tahun 2004 tentang Pemeriksaan Pengelolaan dan Tanggung Jawab Keuangan Negara, Badan Pemeriksa Keuangan (BPK) melaksanakan pemeriksaan atas pengelolaan dan tanggung jawab keuangan negara/daerah, yang terdiri atas pemeriksaan keuangan, pemeriksaan kinerja, dan pemeriksaan dengan tujuan tertentu (Raba, 2017). Laporan hasil pemeriksaan menghasilkan suatu rekomendasi yang wajib ditindaklanjuti oleh pejabat pemerintah daerah. Dalam rangka menjalankan kegiatan pemantauan tindak lanjut hasil pemeriksaan, maka diterbitkan Peraturan BPK Nomor 2 Tahun 2017 tentang Pemantauan Pelaksanaan Tindak Lanjut Rekomendasi Hasil Pemeriksaan BPK, untuk menggantikan Peraturan BPK Nomor 2 Tahun 2010 yang mengatur perihal yang sama (Indonesia, 2007).

Data rekapitulasi hasil pemeriksaan tahun 2005 sampai dengan tahun 2018 di BPK Perwakilan Provinsi Jawa Tengah menunjukkan bahwa dalam pelaksanaan pemantauan tindak lanjut terdapat sebanyak 11.254 temuan dengan rekomendasi sebanyak 25.849. Terdapat perbedaan antara jumlah temuan dengan rekomendasi karena dalam satu temuan ada yang rekomendasinya lebih dari satu. Dari sebanyak 25.847 rekomendasi tersebut, sebanyak 22.269 tindak lanjut telah sesuai dengan rekomendasi (TS), sebanyak 3.212 tindaklanjut belum sesuai dengan rekomendasi (TB), sebanyak 361 belum ditindaklanjuti (BT) dan sebanyak 9 rekomendasi tidak dapat ditindaklanjuti dengan alasan yang sah (TD), dengan rincian:

\section{Tabel 1}

Tindak Lanjut Pemerintah Daerah di Provinsi Jawa Tengah sampai dengan Semester I Tahun 2018

\begin{tabular}{clrcccc}
\hline \multirow{2}{*}{ No. } & \multirow{2}{*}{ Pemda } & \multicolumn{4}{c}{ Status Tindak Lanjut } & \multirow{2}{*}{ Jumlah } \\
\cline { 3 - 6 } & & TS & TB & BT & TD & \\
\hline 1. & Prov. Jawa Tengah & 1.157 & 176 & 102 & - & 1.435 \\
\hline 2. & Kabupaten Banjarnegara & 745 & 43 & 4 & - & 792 \\
\hline 3. & Kabupaten Banyumas & 607 & 75 & - & - & 682 \\
\hline 4. & Kabupaten Batang & 450 & 92 & 1 & - & 543 \\
\hline 5. & Kabupaten Blora & 643 & 53 & - & - & 696 \\
\hline 6. & Kabupaten Boyolali & 628 & 13 & - & - & 641 \\
\hline 7. & Kabupaten Brebes & 594 & 200 & 7 & - & 801 \\
\hline 8. & Kabupaten Cilacap & 756 & 60 & 20 & - & 836 \\
\hline 9. & Kabupaten Demak & 563 & 52 & - & - & 615 \\
\hline 10. & Kabupaten Grobogan & 647 & 91 & 5 & - & 743 \\
\hline 11. & Kabupaten Jepara & 484 & 70 & - & 1 & 555 \\
\hline 12. & Kabupaten Karanganyar & 588 & 52 & 11 & - & 651 \\
\hline
\end{tabular}




\begin{tabular}{|c|c|c|c|c|c|c|}
\hline \multirow{2}{*}{ No. } & \multirow{2}{*}{ Pemda } & \multicolumn{4}{|c|}{ Status Tindak Lanjut } & \multirow{2}{*}{ Jumlah } \\
\hline & & TS & TB & BT & TD & \\
\hline 13. & Kabupaten Kebumen & 592 & 23 & 54 & - & 669 \\
\hline 14. & Kabupaten Kendal & 561 & 131 & 2 & - & 694 \\
\hline 15. & Kabupaten Klaten & 687 & 79 & 2 & - & 768 \\
\hline 16. & Kabupaten Kudus & 689 & 74 & - & 2 & 765 \\
\hline 17. & Kabupaten Magelang & 765 & 134 & - & - & 899 \\
\hline 18 & Kabupaten Pati & 563 & 93 & - & - & 656 \\
\hline 19. & Kabupaten Pekalongan & 494 & 60 & - & - & 554 \\
\hline 20. & Kabupaten Pemalang & 574 & 101 & 34 & - & 709 \\
\hline 21. & Kabupaten Purbalingga & 533 & 114 & 35 & - & 682 \\
\hline 22. & Kabupaten Purworejo & 648 & 86 & 13 & - & 747 \\
\hline 23. & Kabupaten Rembang & 592 & 127 & - & - & 719 \\
\hline 24. & Kabupaten Semarang & 515 & 58 & 33 & - & 606 \\
\hline 25. & Kabupaten Sragen & 631 & 49 & - & 1 & 681 \\
\hline 26. & Kabupaten Sukoharjo & 611 & 112 & - & - & 723 \\
\hline 27. & Kabupaten Tegal & 545 & 60 & - & - & 605 \\
\hline 28. & Kabupaten Temanggung & 539 & 53 & - & - & 592 \\
\hline 29. & Kabupaten Wonogiri & 550 & 12 & - & 1 & 563 \\
\hline 30. & Kabupaten Wonosobo & 593 & 222 & 8 & 1 & 824 \\
\hline 31. & Kota Magelang & 664 & 115 & - & - & 779 \\
\hline 32. & Kota Pekalongan & 507 & 67 & 7 & - & 580 \\
\hline 33. & Kota Salatiga & 555 & 78 & - & 2 & 635 \\
\hline 34. & Kota Semarang & 787 & 159 & 24 & 1 & 971 \\
\hline 35. & Kota Surakarta & 616 & 76 & - & - & 692 \\
\hline 36. & Kota Tegal & 605 & 138 & 3 & - & 746 \\
\hline & Jumlah Total & 22.278 & 3.198 & 365 & 9 & 25.849 \\
\hline
\end{tabular}

Sumber: Rekapitulasi Tindak Lanjut Rekomendasi Hasil Pemeriksaan BPK perwakilan Provinsi Jawa Tengah

Berdasarkan data hasil rekapitulasi pada Tabel 1 di atas diketahui bahwa seluruh pemerintah daerah di Jawa Tengah telah menindaklanjuti rekomendasi hasil pemeriksaan BPK, dan masih ada sebagian pemerintah daerah yang belum menindaklanjuti rekomendasi serta tidak dapat menindaklanjuti dengan alasan yang sah.

Padahal Peraturan BPK Nomor 2 Tahun 2017 pada Pasal 3 juncto UU Nomor 15 Tahun 2004 Pasal 20 mengatur bahwa pejabat wajib menindaklanjuti rekomendasi dalam laporan hasil pemeriksaan setelah hasil pemeriksaan diterima. Dalam hal sebagian atau seluruh rekomendasi tidak dapat dilaksanakan, pejabat wajib memberikan alasan yang sah. Pejabat juga wajib memberikan jawaban atau penjelasan kepada BPK tentang tindak lanjut atas rekomendasi dalam laporan hasil pemeriksaan yang dilampiri dengan dokumen pendukung. Jawaban atau penjelasan tersebut disampaikan kepada BPK paling lambat 60 hari setelah laporan hasil pemeriksaan BPK diterima oleh DPRD dan Kepala Daerah. Selain itu, dalam UU Nomor 15 Tahun 2004 Pasal 20 ini juga mengatur bahwa pejabat yang diketahui tidak melaksanakan kewajiban tersebut dapat dikenai sanksi administratif sesuai dengan ketentuan peraturan perundang-undangan di bidang kepegawaian (Korje, 2016). 
Berdasarkan berbagai informasi yang telah diuraikan di atas, diketahui bahwa dengan adanya rekomendasi yang belum ditindaklanjuti tersebut, menunjukkan bahwa masih terdapat pejabat dari pemerintah daerah yang bersangkutan menindaklanjuti rekomendasi lebih dari 60 hari. Terdapat juga kondisi rekomendasi yang telah ditindaklanjuti dalam jangka waktu 60 hari namun belum sesuai dengan rekomendasi dan masih dalam proses penyelesaian. Tindak lanjut atas rekomendasi dapat berupa pelaksanaan seluruh atau sebagian dari rekomendasi. Sehingga dokumen pendukung yang disampaikan belum membuktikan adanya penyelesaian rekomendasi laporan hasil pemeriksaan dan penyelesaian tindak lanjut atas rekomendasi terkait dengan pihak di luar entitas. Atas rekomendasi yang belum ditindaklanjuti tersebut belum ada pengenaan sanksi administratis dimaksud (Halim \& Bawono, 2011).

Peraturan BPK Nomor 2 Tahun 2017 pada Pasal 5 mengatur bahwa dalam hal tindak lanjut atas rekomendasi tidak dapat dilaksanakan dalam jangka waktu paling lambat 60 (enam puluh) hari, pejabat wajib memberikan alasan yang sah. Alasan sah ini tidak membebaskan Pejabat dari kewajiban untuk menindaklanjuti rekomendasi hasil pemeriksaan. Dengan masih adanya tindak lanjut yang belum ditindaklanjuti menunjukkan bahwa pejabat yang menindaklanjuti melebihi waktu 60 hari belum menyampaikan alasan sahnya kepada BPK. Apabila sudah menyampaikan alasan yang sah, maka status tindak lanjutnya dapat berada pada status tindak lanjut belum sesuai dengan rekomendasi atau hanya sekedar tercatat di keterangan mengapa belum ditindaklanjuti. Sementara itu, sampai dengan saat ini belum ada catatan keterangan mengapa rekomendasi belum ditindaklanjuti (Howlett \& Rayner, 1995).

Dari sebanyak 36 pemerintah daerah (provinsi/kabupaten/kota) di Jawa Tengah, dapat diuraikan persentase penyelesaian tindak lanjut yang telah sesuai dengan rekomendasi dari yang tertinggi ke yang terendah adalah sebagai berikut.

\section{Tabel 2}

Persentase Penyelesaian Tindak Lanjut Rekomendasi LHP BPK sampai dengan tahun 2018

\begin{tabular}{clc}
\hline No. & \multicolumn{1}{c}{ Pemda } & Persentase Penyelesaian \\
\hline 1. & Kabupaten Boyolali & $97,97 \%$ \\
\hline 2. & Kabupaten Wonogiri & $97,69 \%$ \\
\hline 3. & Kabupaten Banjarnegara & $94,07 \%$ \\
\hline 4. & Kabupaten Sragen & $92,67 \%$ \\
\hline 5. & Kabupaten Blora & $92,39 \%$ \\
\hline 6. & Kabupaten Demak & $91,54 \%$ \\
\hline 7. & Kabupaten Temanggung & $91,05 \%$ \\
\hline 8. & Kabupaten Cilacap & $90,43 \%$ \\
\hline 9. & Kabupaten Karanganyar & $90,32 \%$ \\
\hline 10. & Kabupaten Tegal & $90,08 \%$ \\
\hline 11. & Kabupaten Kudus & $90,07 \%$ \\
\hline 12. & Kabupaten Klaten & $89,45 \%$ \\
\hline 13. & Kabupaten Pekalongan & $89,17 \%$ \\
\hline
\end{tabular}




\begin{tabular}{|c|c|c|}
\hline No. & Pemda & Persentase Penyelesaian \\
\hline 14. & Kabupaten Banyumas & $89,00 \%$ \\
\hline 15. & Kabupaten Kebumen & $88,49 \%$ \\
\hline 16. & Kota Surakarta & $87,57 \%$ \\
\hline 17. & Kota Pekalongan & $87,41 \%$ \\
\hline 18 & Kota Salatiga & $87,40 \%$ \\
\hline 19. & Kabupaten Jepara & $87,21 \%$ \\
\hline 20. & Kabupaten Grobogan & $87,08 \%$ \\
\hline 21. & Kabupaten Purworejo & $86,75 \%$ \\
\hline 22. & Kabupaten Pati & $85,82 \%$ \\
\hline 23. & Kabupaten Semarang & $85,41 \%$ \\
\hline 24. & Kota Magelang & $85,24 \%$ \\
\hline 25. & Kabupaten Magelang & $85,09 \%$ \\
\hline 26. & Kabupaten Sukoharjo & $84,51 \%$ \\
\hline 27. & Kabupaten Batang & $82,87 \%$ \\
\hline 28. & Kabupaten Rembang & $82,34 \%$ \\
\hline 29. & Kota Tegal & $81,10 \%$ \\
\hline 30. & Kota Semarang & $81,05 \%$ \\
\hline 31. & Kabupaten Pemalang & $80,96 \%$ \\
\hline 32. & Kabupaten Kendal & $80,84 \%$ \\
\hline 33. & Prov. Jawa Tengah & $80,63 \%$ \\
\hline 34. & Kabupaten Purbalingga & $78,15 \%$ \\
\hline & Kabupaten Brebes & $74,16 \%$ \\
\hline 36. & Kabupaten Wonosobo & $71,97 \%$ \\
\hline
\end{tabular}

Sumber: Rekapitulasi Tindak Lanjut Rekomendasi Hasil Pemeriksaan BPK Perwakilan Provinsi Jawa Tengah

Dari data Tabel 2 di atas diketahui bahwa Pemerintah Kabupaten Wonosobo mempunyai persentase penyelesaian terendah dibandingkan dengan daerah lain di wilayah Provinsi Jawa Tengah dengan persentase sebesar 71,97\% (593 dari 824 rekomendasi telah sesuai/selesai ditindaklanjuti). Dengan pertimbangan, sehingga penelitian ini dilakukan di Pemerintah Kabupaten Wonosobo.

Permasalahan terkait tindak lanjut ini juga menjadi perhatian peneliti lainnya, antara lain dilakukan oleh: (Purba, 2014) yang hasil penelitiannya menunjukkan bahwa terjadi perkembangan yang positif dan signifikan atas opini LKPD. Charles Bohlen Purba juga merincikan persentase status tindak lanjut di masing-masing pemerintah daerah di Kalimantan Barat, Tengah, dan Timur, berapa persen rekomendasi BPK telah ditindaklanjuti dari masing-masing status tindak lanjut. Kemudian (Arianto, Heriyanto, \& Karneli, 2018) dengan hasil penelitiannya menunjukkan bahwa semakin banyak permasalahan kelemahan SPI dan penyimpangan atas peraturan perundang-undangan yang ditemukan oleh BPK selama pemeriksaan pada tahun tersebut, maka dengan tindak lanjut perbaikan yang memadai akan mendorong BPK untuk memberikan opini atas kewajaran penyajian laporan keuangan pada tahun tersebut menjadi lebih baik. 
Selanjutnya ada (Lusiana, Djamhuri, \& Prihatiningtias, 2017) yang hasil penelitiannya menunjukkan terdapat banyak kelemahan dalam proses penyelesaian TLHP yang menyebabkan penyelesaian TLHP belum optimal. Selanjutnya hasil penelitian (Tresnawati, 2016) yang menyatakan bahwa tindak lanjut hasil pemeriksaan dapat memperbaiki kualitas laporan keuangan. Jadi semakin tinggi tindak lanjut hasil rekomendasi, maka semakin baik kualitas laporan keuangan. Dengan demikian ada benang merah disini bahwa semakin banyak penyelesaian tindak lanjut yang menyebabkan permasalahan di pengelolaan keuangan daerah, maka laporan keuangan pemerintah daerah akan semakin baik dan akuntabel, untuk selanjutnya mendapatkan opini yang baik dan wajar dari BPK.

Oleh karena itu, efektifitas tindak lanjut hasil pemeriksaan ini, pada akhirnya ditentukan sejauh mana entitas pemeriksaan, dalam hal ini adalah pemerintah daerah, melakukan tindak lanjut rekomendasi hasil pemeriksaan BPK. Pejabat pemerintah daerah melakukan tindak lanjut rekomendasi hasil pemeriksaan BPK merupakan salah satu fungsi/tugas aparatur pemerintahan dalam menjalankan kegiatan administrasi negara. hal ini selaras dengan apa yang dikemukakan oleh (Anggara, 2012) yang menyatakan bahwa administrasi negara mempunyai tiga pengertian pokok, yaitu administrasi negara sebagai fungsi/tugas pemerintah, administrasi negara sebagai aparatur pemerintahan, dan administrasi negara sebagai proses teknis pengerjaan.

Penelitian ini bertujuan untuk menganalisis efektifitas pemerintah daerah dalam melaksanakan tindak lanjut atas rekomendasi hasil pemeriksaan pengelolaan dan tanggung jawab keuangan daerah supaya tidak muncul lagi permasalahan serupa di pemeriksaan tahun berikutnya.

\section{Metode Penelitian}

Sebagaimana dikemukakan oleh (Singarimbun \& Effendi, 2019) bahwa ada beberapa jenis penelitian, antara lain penelitian survei, eksperimen, grounded research, kombinasi pendekatan kualitatif dan kuantitatif, dan analisa data sekunder. Penelitian ini dilakukan dengan pendekatan kualitatif (Cresswell, 2017), observasi di lapangan, analisis data sekunder dan wawancara dengan informan yang dipilih yaitu pejabat teknis di Inspektorat, BPPKAD, pejabat dan auditor BPK Perwakilan Provinsi Jawa Tengah yang menangani pemantauan tindak lanjut dan informan yang dipilih secara acak berdasarkan perkembangan penelitan atau permasalahan yang terjadi di lapangan. Instrumen penelitian ini adalah diri peneliti sendiri, informan, dan wawancara. Adapun alat bantu yang dapat digunakan dalam penelitian ini antara lain handphone, laptop, dokumen-dokumen yang berhubungan dengan penelitian ini, ATK, dan alat bantu lainnya. Teknik analisa data yang digunakan adalah dengan analisa kepustakaan dan dokumen yang memiliki keterkaitan dengan penelitian ini, pengamatan langsung (observasi) di lapangan, dan dengan wawancara dilakukan secara terbuka (Moleong, 2007). 


\section{Hasil dan Pembahasan}

Kewenangan pemberian status tindak lanjut yang telah sesuai dengan rekomendasi dan status tidak dapat ditindaklanjuti dengan alasan yang sah ada pada Anggota BPK. Sedangkan pemberian status tindak lanjut belum sesuai dengan rekomendasi dan status belum ditindaklanjuti ada pada Kepala Perwakilan BPK. Hal ini berpengaruh pada perbedaan kepastian status tindak lanjut pada saat dilaksanakannya tugas pemantauan tindak lanjut oleh BPK yang tidak dapat segera disampaikan sesegera mungkin kepada pemerintah daerah atas status tindak lanjut telah sesuai dengan rekomendasi dan status rekomendasi tidak dapat ditindaklanjuti dengan alasan yang sah karena membutuhkan waktu lebih lama atas proses penyampaian berjenjang untuk ditetapkan oleh Anggota BPK. Hal tersebut berbeda dengan status tindak lanjut belum sesuai dengan rekomendasi dan status rekomendasi belum ditindaklanjuti yang segera bisa disampaikan dan dikomunikasikan kepada pemerintah daerah (Tjandra, 2006).

Dalam tabel 3 dibawah ini dapat diketahui bahwa dari tahun 2005 sampai dengan tahun 2018 telah dilakukan 24 kali pemeriksaan dengan jumlah temuan sebanyak 348 dengan diberikan sebanyak 824 rekomendasi. Dari rekomendasi tersebut telah selesai ditindaklanjuti (TS) sebanyak 593 rekomendasi, belum selesai ditindaklanjuti dan masih dalam proses penyelesaian (TB) sebanyak 222 rekomendasi, belum ditindaklanjuti (BT) sebanyak 8 rekomendasi, dan 1 rekomendasi tidak dapat ditindaklanjuti dengan alasan yang sah (TD). Tindak lanjut rekomendasi hasil pemeriksaan di Pemerintah Kabupaten Wonosobo Tahun 2005 s.d 2018 dapat diuraikan dalam tabel 3 berikut ini:

Tabel 3

Rekapitulasi Tindak Lanjut Rekomendasi Hasil Pemeriksaan di Pemkab Wonosobo Tahun 2005 s.d 2018

\begin{tabular}{clcccccc}
\hline \multirow{2}{*}{ No. } & \multirow{2}{*}{ Tahun dan Obyek Pemeriksaan } & \multicolumn{2}{c}{ Pemeriksaan } & \multicolumn{3}{c}{$\begin{array}{c}\text { Status Tindak } \\
\text { Lanjut }\end{array}$} \\
\cline { 3 - 8 } & & Temuan & Rekomendasi & TS & TB & B T & TD \\
\hline 1. & 2018: LKPD TA 2017 & 22 & 42 & 21 & 20 & 1 & 0 \\
\hline 2. & 2017: PAD TA 2017 & 13 & 72 & 15 & 57 & 0 & 0 \\
\hline & 2017: LKPD TA 2016 & 16 & 52 & 26 & 26 & 0 & 0 \\
\hline 3. & 2016: Kinerja JKN TA 2016 & 14 & 38 & 13 & 25 & 0 & 0 \\
\hline & 2016: LKPD TA 2015 & 20 & 50 & 22 & 28 & 0 & 0 \\
\hline 4. & 2015: Belanja Modal TA 2015 & 6 & 15 & 8 & 7 & 0 & 0 \\
\hline & 2015: LKPD TA 2014 & 14 & 38 & 21 & 16 & 1 & 0 \\
\hline 5. & 2014: Kinerja PDAM & 11 & 39 & 28 & 8 & 3 & 0 \\
\hline & 2014: LKPD TA 2013 & 12 & 30 & 18 & 10 & 2 & 0 \\
\hline 6. & 2013: Kinerja Operasional RSUD & 18 & 58 & 54 & 4 & 0 & 0 \\
& TA 2012-2013 & & & & & & \\
\hline & 2013: LKPD TA 2012 & 14 & 23 & 20 & 3 & 0 & 0 \\
\hline 7. & 2012: LKPD TA 2011 & 19 & 52 & 52 & 0 & 0 & 0 \\
\hline 8. & 2011: PAD TA 2010 2011 & 22 & 45 & 44 & 1 & 0 & 0 \\
\hline & 2011- LKPD TA 2010 & 19 & 30 & 30 & 0 & 0 & 0 \\
\hline
\end{tabular}




\begin{tabular}{llcccccc}
\hline \multirow{2}{*}{ No. } & \multirow{2}{*}{ Tahun dan Obyek Pemeriksaan } & \multicolumn{2}{c}{ Pemeriksaan } & \multicolumn{4}{c}{$\begin{array}{c}\text { Status Tindak } \\
\text { Lanjut }\end{array}$} \\
\cline { 3 - 8 } & & Temuan & Rekomendasi & TS & TB & B T & TD \\
\hline 9. & 2010: Belanja Daerah TA 2009 & 14 & 36 & 31 & 4 & 0 & 1 \\
\hline & 2010:LKPD TA 2009 & 17 & 35 & 34 & 1 & 0 & 0 \\
\hline 10. & 2009: LKPD TA 2008 & 19 & 31 & 29 & 2 & 0 & 0 \\
\hline 11. & 2008: LKPD TA 2007 & 25 & 51 & 50 & 1 & 0 & 0 \\
\hline 12. & 2007: Dana Perimbangan & 3 & 3 & 2 & 1 & 0 & 0 \\
\hline & $\begin{array}{l}\text { 2007: Bantuan Keuangan Partai } \\
\text { Politik TA 2006 }\end{array}$ & 4 & 4 & 4 & 0 & 0 & 0 \\
\hline & 2007: LKPD TA 2006 & 10 & 19 & 17 & 2 & 0 & 0 \\
\hline 13. & 2006: Belanja Daerah TA 2005- & 15 & 31 & 27 & 3 & 1 & 0 \\
& 2006 & & & & & & \\
\hline & 2006: LKPD TA 2005 & 10 & 15 & 13 & 2 & 0 & 0 \\
\hline 14. & 2005: LKPD TA 2004 & 11 & 15 & 14 & 1 & 0 & 0 \\
\hline & Jumlah & $\mathbf{3 4 8}$ & $\mathbf{8 2 4}$ & $\mathbf{5 9 3}$ & $\mathbf{2 2 2}$ & $\mathbf{8}$ & $\mathbf{1}$ \\
\hline
\end{tabular}

Sumber: TLRHP Kabupaten Wonosobo Semester 2 Tahun 2018

Rekomendasi yang belum selesai ditindaklanjuti sebanyak 222 tersebut masih dalam proses penyelesaian oleh pihak Pemerintah Kabupaten Wonosobo berpotensi masih terjadi permasalahan serupa pada tahun-tahun berikutnya yang akan datang. Hal ini dapat dilihat dari hasil pemeriksaan atas sistem pengendalian internal (SPI) atas laporan keuangan Pemerintah Daerah dalam 3 tahun terakhir dari tahun 2015 sampai dengan tahun 2017 sebagai berikut.

a. Laporan Hasil Pemeriksaan BPK RI atas Laporan Keuangan Pemerintah Daerah Kabupaten Wonosobo Tahun 2017 memuat temuan pemeriksaan atas sistem pengendalian intern atas pengelolaan kas di kas daerah TA 2017 belum memadai, pengelolaan kas di Bendahara Pengeluaran pada beberapa OPD belum memadai, pengelolaan Tabulin (Tabungan Bersalin) sebesar Rp613.077.362,00 tidak tertib, Pengakuan Piutang BPHTB belum sesuai SAP, pengelolaan persediaan pada Pemerintah Kabupaten Wonosobo TA 2017 belum memadai, saldo uang muka sebesar Rp150.000.000,00 dan saldo persediaan sebesar Rp14.274.218,00 pada PT GDA belum dapat diyakini kewajarannya, terdapat aset jalan dan tanah jalan yang belum dicatat dan terdapat ruas jalan di lingkungan kelurahan yang belum ditetapkan statusnya, fasilitas umum dan fasilitas sosial perumahan belum diserahkan oleh pengembang, pengelolaan tunjangan profesi guru dan tambahan penghasilan pada Dinas Pendidikan Pemuda dan Olahraga belum memadai, perhitungan dan pembayaran iuran Jaminan Keselamatan Kerja dan Jaminan Kematian (JKK-JKM) belum sepenuhnya sesuai ketentuan, belanja listrik PJU sebesar Rp.2.800.204.572,00 belum dapat diyakini kewajarannya, pemborosan pada kegiatan padat karya sebesar Rp.24.192.118,80, pengelolaan pertanggungjawaban bantuan keuangan partai politik belum memadai, dan kesalahan penganggaran senilai Rp8.188.298.785,00 pada APBD/APBD-Perubahan Kabupaten Wonosobo TA 2017. 
b. Laporan Hasil Pemeriksaan BPK RI atas Laporan Keuangan Pemerintah Daerah Kabupaten Wonosobo Tahun 2016, memuat temuan pemeriksaan atas sistem pengendalian intern atas pengelolaan dan penatausahaan kas Kabupaten Wonosobo belum memadai, penyajian piutang pajak daerah Kabupaten Wonosobo tidak didukung dengan dokumen yang memadai, pengelolaan aset tetap belum sepenuhnya tertib, aset tanah dan bangunan Pasar Induk (Pasar Atas) Wonosobo hasil kemitraan Pemerintah Kabupaten Wonosobo yang dikerjasamakan dengan pihak ketiga belum sepenuhnya dikuasai oleh Pemerintah Kabupaten Wonosobo.

c. Laporan Hasil Pemeriksaan BPK RI atas Laporan Keuangan Pemerintah Daerah Kabupaten Wonosobo Tahun 2015, memuat temuan pemeriksaan atas sistem pengendalian intern atas kelemahan penatausahaan keuangan pada Pemerintah Kabupaten Wonosobo, data piutang pajak daerah per 31 Desember 2015 belum akurat, pengelolaan aset tetap belum sepenuhnya memadai, pengelolaan pendapatan pajak hotel belum optimal, pengelolaan kios/los pasar pada Pemerintah Kabupaten Wonosobo belum optimal, pengelolaan aset tanah Pemerintah Kabupaten Wonosobo yang dikerjasamakan dengan pihak ketiga untuk pembangunan kembali Pasar Induk Wonosobo belum memadai, kelemahan penyajian dana BOS dalam Laporan Keuangan Pemerintah Kabupaten Wonosobo.

Dari uraian data di atas diketahui bahwa dalam laporan hasil pemeriksaan atas sistem pengendalian intern laporan keuangan pemerintah daerah Kabupaten Wonosobo selama 3 tahun berturut-turut terdapat permasalahan serupa yang terjadi setiap tahun, yaitu permasalahan mengenai pengelolaan dan penatausahaan aset tetap. Permasalahan serupa lain yang masih ada di tahun-tahun berikutnya meski tidak setiap tahun muncul adalah permasalahan penatausahaan keuangan daerah, pengelolaan persediaan, dan piutang. Berdasarkan hasil observasi dan wawancara dengan Ketua Tim pemeriksaan di BPK Perwakilan Provinsi Jawa Tengah, diperoleh ketrangan bahwa hasil pemeriksaan atas Sistem Pengendalian Intern inilah yang seringkali menjadi bahan pertimbangan kualifikasi opini pengelolaan keuangan daerah oleh BPK. Laporan hasil pemeriksaan BPK atas laporan keuangan pemerintah daerah terdiri dari 3 buku yang merupakan satu kesatuan yang tidak terpisahkan, yaitu Buku I terkait dengan Laporan Hasil Pemeriksaan atas Laporan Keuangan, Buku II terkait dengan Laporan Hasil Pemeriksaan atas Sistem Pengendalian Intern, dan Buku III terkait dengan Laporan Hasil Pemeriksaan atas Kepatuhan Terhadap Peraturan Perundang-Undangan. Hasil pemeriksaan di Buku II lah yang seringkali menjadi bahan pertimbangan kualifikasi opini pengelolaan keuangan daerah

Berdasarkan tabel 1 terdapat 8 rekomendasi hasil pemerikaan yang statusnya belum ditindaklanjuti, yang berasal dari sebanyak 8 temuan pemeriksaan dengan uraian: 
Tabel 4

Laporan Hasil Pemeriksaan yang Rekomendasinya Belum ditindaklanjuti

\begin{tabular}{|c|c|c|c|}
\hline \multirow[b]{2}{*}{ No. } & \multirow[b]{2}{*}{ Judul LHP BPK } & \multicolumn{2}{|c|}{ Jumlah } \\
\hline & & $\begin{array}{c}\text { Rekomendasi } \\
\text { Belum } \\
\text { Ditindaklanjuti }\end{array}$ & Temuan \\
\hline 1. & $\begin{array}{l}\text { Laporan Hasil Pemeriksaan atas Laporan Keuangan } \\
\text { Pemerintah Daerah Kabupaten Wonosobo Tahun } 2017\end{array}$ & 1 & 1 \\
\hline 2. & $\begin{array}{l}\text { Laporan Hasil Pemeriksaan BPK RI atas Laporan } \\
\text { Keuangan Pemerintah Daerah Kabupaten Wonosobo } \\
\text { Tahun } 2014\end{array}$ & 1 & 1 \\
\hline 3. & $\begin{array}{l}\text { Laporan Hasil Pemeriksaan Kinerja atas Penyediaan } \\
\text { Air Bersih Pemerintah Kabupaten Wonosobo, PDAM } \\
\text { Tirta Aji danan Instansi Terkait Lainnya Di Wonosobo } \\
\text { Tahun } 2013 \text { dan Semester I Tahun } 2014\end{array}$ & 3 & 3 \\
\hline 4. & $\begin{array}{l}\text { Laporan Hasil Pemeriksaan BPK RI atas Laporan } \\
\text { Keuangan Pemerintah Daerah Kabupaten Wonosobo } \\
\text { Tahun } 2013\end{array}$ & 2 & 2 \\
\hline 5. & $\begin{array}{l}\text { Hasil Pemeriksaan atas Belanja Daerah Kabupaten } \\
\text { Wonosobo Tahun Anggaran } 2005 \text { dan } 2006\end{array}$ & 1 & 1 \\
\hline & Total & 8 & 8 \\
\hline
\end{tabular}

Sumber: LHP BPK dan TLRHP Kabupaten Wonosobo Semester 2 Tahun 2018

Rincian lebih lanjut dari 8 temuan dan rekomendasi yang berasal dari 5 laporan hasil pemeriksaan BPK dapat diuraikan di sebagai berikut:

a. Laporan Hasil Pemeriksaan atas Laporan Keuangan Pemerintah Daerah Kabupaten Wonosobo Tahun 2017 dengan Nomor 63/LHP/BPK/XVIII.SMG/05/2018 tanggal 23 Mei 2018 pada temuan pemeriksaan terkait dengan pengelolaan persediaan yang belum memadai, dengan rekomendasi agar Bupati Wonosobo memerintahkan Kepala Dinas PUPR untuk menugaskan Bendahara Pengeluaran Dinas PUPR untuk mengikuti pelatihan terkait pertanggungjawaban belanja bahan pakai habis.

b. Laporan Hasil Pemeriksaan BPK RI atas Laporan Keuangan Pemerintah Daerah Kabupaten Wonosobo Tahun 2014 dengan Nomor 25/LHP/BPK/XVIII.SMG/05/2015 tanggal 05 Mei 2015 pada temuan pemeriksaan terkait keterlambatan penyampaian laporan pertanggungjawaban belanja hibah. Rekomendasinya adalah agar Bupati Wonosobo memberikan sanksi sesuai dengan ketentuan yang berlaku kepada penerima hibah karena tidak melaksanakan kewajibannya atas pelaksanaan dan pelaporan pertanggungjawaban dana hibah.

c. Laporan Hasil Pemeriksaan Kinerja atas Penyediaan Air Bersih Pemerintah Kabupaten Wonosobo, PDAM Tirta Aji dan Instansi Terkait Lainnya Di Wonosobo Tahun 2013 dan Semester I Tahun 2014 dengan Nomor 400 C/LHP/BPK/XVIII.SMG/11/2014 Tanggal 7 November 2014 dengan temuan pemeriksaan: pertama, PDAM belum memiliki corporate plan atau bussiness plan, dengan rekomendasi agar Pemerintah Kabupaten Wonosobo tidak menarik deviden 
selama PDAM belum mencapai cakupan pelayanan 80\%. Selanjutnya temuan pemeriksaan kedua, PDAM belum memiliki unsur kelembagaan, tata laksana, dan sumberdaya penyediaan air bersih yang memadai, dengan rekomendasi agar Bupati Wonosobo memerintahkan kepada Dewan Pengawas supaya dalam melaksanakan tugas dan wewenang sesuai Permen PU Nomor 18 Tahun 2007 tentang Penyelenggaraan Pengembangan SPAM dan Permen PU Nomor 18/M/PRT/2012 tentang Pembinaan Penyelenggaraan SPAM, dan yang ketiga PDAM belum memiliki pedoman pemeliharaan dan perbaikan instalasi produksi dan jaringan distribusi untuk meningkatkan kualitas, kuantitas, dan kontinuitas air bersih, dengan rekomendasi Bupati Wonosobo agar tetap memperhitungkan penggunaan air PDAM pada TR kalianget selama TR Kalianget belum memperoleh aliran air dari Sumber mata air Baru.

d. Laporan Hasil Pemeriksaan BPK RI atas Laporan Keuangan Pemerintah Daerah Kabupaten Wonosobo Tahun 2013 Nomor 28/LHP/BPK/ XVIII.SMG/05/2014 tanggal 6 Mei 2014, dengan rincian: pertama, pada temuan mengenai pengelolaan pendapatan retribusi pemakaian kekayaan daerah dan hasil lelang eks tanah bengkok pada Pemerintah Kabupaten Wonosobo tidak sesuai ketentuan Senilai Rp363.084.000,00. Direkomendasikan kepada Bupati Wonosobo agar memerintahkan Lurah Sapuran untuk memerintahkan penyimpan uang hasil lelang eks tanah bengkok agar menyetorkan hasil lelang sebesar Rp21.234.000,00 ke kas daerah, dan yang kedua, pada temuan mengenai Bendahara Pengeluaran terlambat menyampaikan Laporan Pertanggungjawaban Fungsional kepada PPKD selaku BUD, rekomendasi yang ditujukan kepada Bupati Wonosobo adalah agar memerintahkan BUD untuk menetapkan batas waktu penyampaian SPM dan penerbitan SP2D akhir tahun dan menjalankannya secara tegas.

e. Laporan Hasil Pemeriksaan atas Belanja Daerah Kabupaten Wonosobo Tahun Anggaran 2005 dan 2006 Nomor 06/R/XIV.YK/01/2007 Tanggal 11 Januari 2007 pada temuan pemeriksaan mengenai kegiatan ganti rugi tanah untuk pengembangan kawasan wisata Dieng TA 2006 dilaksanakan tidak sesuai ketentuan, dengan rekomendasi ditujukan kepada Bupati Wonosobo agar memerintahkan Kepala Dinas Pariwisata selaku Pengguna Angggaran untuk menarik kerugian daerah sebesar Rp125.670.000,00 dan menyetorkannya ke kas daerah.

Dari uraian di atas diketahui bahwa terdapat temuan pemeriksaan atas laporan keuangan daerah di tahun berikutnya (dalam hal ini tahun 2017) yang serupa dengan permasalahan di pemeriksaan tahun sebelumnya (dalam hal ini tahun 2013 dan 2014), yaitu permasalahan terkait pengelolaan persediaan, meskipun rekomendasi hasil pemeriksaan pada tahun sebelumnya telah ditindaklanjuti, dan dengan rekomendasi yang belum tentu sama dan berbeda.

Berdasarkan tabel 1 terdapat satu rekomendasi hasil pemerikaan yang statusnya tidak dapat ditindaklanjuti dengan alasan yang sah. Rekomendasi itu berasal hasil pemeriksaan atas belanja daerah Kabupaten Wonosobo pada tahun anggaran 2009 Nomor 86/R/LHP/XVIII.SMG/01/2010 Tanggal 29 Januari 2010 dengan temuan 
mengenai realisasi pengadaan obat di RSUD Setjonegoro tidak sesuai dengan ketentuan tentang pengelolaan keuangan daerah. Rekomendasi atas temuan tersebut BPK menyarankan Bupati Wonosobo untuk menetapkan Peraturan Bupati tentang mekanisme pencairan dana APBD untuk keperluan setiap bulan bagi RSUD yang diprioritaskan untuk belanja yang bersifat mengikat dan belanja yang bersifat wajib sesuai bunyi pasal 132 Permendagri Nomor 13 Tahun 2006. Per tanggal 17 Desember 2012 pihak Inspektorat menyatakan bahwa per Januari 2011, RSUD Wonosobo telah menjadi Badan Layanan Umum Daerah (BLUD) dan sudah bukan merupakan satuan kerja perangkat daerah (SKPD) atau organisasi perangkat daerah (OPD) murni yang pembiayaan kegiatannya hanya mengandalkan dari APBD semata, sehingga rekomendasinya tidak dapat dilaksanakan. Dalam hal ini Pemerintah Kabupaten Wonosobo telah melakukan evaluasi kebijakan dalam menindak lanjuti rekomendasi hasil pemeriksaan, karena dinilai bahwa rekomendasi tersebut sudah tidak relevan lagi untuk dilaksanakan. Sehingga berdasarkan hasil penilaian atau evaluasi tersebut, kebijakan yang diambil untuk menyelesaikan tindakan perbaikan sesuai rekomendasi tersebut dihentikan.

Berdasarkan keterangan dari staf Bagian Evalap dan Perencanaan Inspektorat bahwa di Inspektorat Kabupaten Wonosobo ada program kegiatan untuk menangani tindak lanjut hasil pemeriksaan, baik itu dari pihak internal pemerintah (Inspektorat Kabupaten dan Provinsi, BPKP) maupun pihak eksternal pemerintah (Badan Pemeriksa Keuangan) terdapat mata anggaran kegiatan tersendiri, tujuannya adalah agar prosentase tindak lanjut hasil pemeriksaan meningkat. Untuk pemeriksaan yang berasal dari internal, baik itu dari Inspektorat Kabupaten Wonosobo maupun Inspektorat Provinsi Jawa Tengah sudah tercapai, namun untuk tindak lanjut hasil pemeriksaan dari Badan Pemeriksa Keuangan Perwakilan Provinsi Jawa Tengah belum tercapai.

Rekomendasi yang tidak segera ditindaklanjuti oleh Pemerintah Kabupaten Wonosobo berdampak pada ditemukannya permasalahan yang serupa dalam pemeriksaan BPK atas laporan keuangan pada tahun berikutnya. Permasalahan yang berulang kali ditemui oleh BPK adalah terkait pengelolaan dan penatausahaan keuangan, aset tetap, persediaan dan piutang. Hal ini tentunya menunjukkan bahwa tindak lanjut yang dilakukan oleh Pemerintah Kabupaten Wonosobo belum sepenuhnya efektif dalam meningkatkan akuntabilitas pengelolaan dan pertanggungjawaban keuangan daerah.

BPK telah menerbitkan regulasi berupa Peraturan BPK Nomor 2 Tahun 2017 mengenai pemantauan pelaksanaan tindak lanjut rekomendasi hasil pemeriksaan BPK. Regulasi ini menjadi salah satu pedoman bagi Pemerintah Kabupaten Wonosobo dan pihak BPK Perwakilan Provinsi Jawa Tengah dalam melaksanakan kegiatan pemantauan tindak lanjut rekomendasi hasil pemeriksaan. Selain Peraturan BPK Nomor 2 Tahun 2017 tersebut di atas, BPK juga menerbitkan Keputusan BPK RI Nomor 5/K/IXVIII.2/10/2015, yang mengatur bahwa entitas perlu membuat rencana aksi sebagai bentuk rencana tindak lanjut. Pemantauan menurut Dunn (2003: 509) dapat dimanfaatkan untuk menginformasikan sebab dan akibat yang timbul dari 
dikeluarkannya suatu kebijakan publik. Ketentuan dalam Pasal 2 Peraturan Badan Pemeriksa Nomor 2 Tahun 2017, dapat diilustrasikan bahwa disebabkan oleh Badan Pemeriksa Keuangan (BPK) Perwakilan Provinsi Jawa Tengah menyerahkan laporan hasil pemeriksaan atas pengelolaan dan tanggung jawab keuangan daerah kepada DPRD dan Bupati Wonosobo, maka mengakibatkan DPRD, Bupati Wonosobo, dan/atau Pejabat OPD satuan kerja di lingkungan Pemerintah Kabupaten Wonosobo sebagai terperiksa melakukan suatu tindakan dan/atau langkah perbaikan sebagaimana rekomendasi dalam laporan hasil pemeriksaan.

(Dunn, 2003) juga membagi pemantauan dalam 4 fungsi yaitu: kepatuhan, pemeriksaan, akuntansi, eksplanasi. Fungsi pertama yang terkait dengan kepatuhan (compliance) dapat dikatakan bahwa pemantauan dapat dilakukan untuk menilai sejauh mana para pejabat pemerintahan Kabupaten Wonosobo selaku pelaksana kebijakan mematuhi ketentuan atau aturan di Peraturan BPK Nomor 2 Tahun 2017. Peraturan tersebut mengatur bahwa pejabat Pemerintah Kabupaten Wonosobo wajib melaksanakan tindak lanjut rekomendasi hasil pemeriksaan setelah laporan hasil pemeriksaan diterima, berupa penjelasan atau jawaban tertulis atas pelaksanaan tindakan dan/atau perbaikan sebagaimana direkomendasikan dalam laporan hasil pemeriksaan, yang wajib disampaikan dalam kurun waktu 60 hari setelah laporan tersebut diterima. Bahwa terdapat rekomendasi hasil pemeriksaan yang belum ditindaklanjuti, sudah merupakan suatu bukti bahwa terdapat ketidakpatuhan dari pejabat Pemerintah Kabupaten Wonosobo Peraturan BPK Nomor 2 Tahun 2017. Ketidakpatuhan pertama Pejabat terperiksa di lingkungan Pemerintah Kabupaten Wonosobo belum memenuhi kewajibannya dalam melaksanakan tindak lanjut atas rekomendasi pada saat diterimana laporan hasil pemeriksaan. Ketidakpatuhan kedua yaitu disebabkan oleh Pejabat terperiksa di lingkungan Pemerintah kabupaten Wonosobo belum melakukan tindak lanjut, maka berakibat belum adanya penjelasan atau jawaban tertulis atas pelaksanaan tindak lanjut rekomendasi hasil pemeriksaan. Ketidakpatuhan ketiga disebabkan belum adanya tindak lanjut atas rekomendasi hasil pemeriksaan yang telah lampau, sehingga mengakibatkan kewajiban menyampaikan data atau dokumen tindak lanjut rekomendasi hasil pemeriksaan telah melewati jangka waktu maksimal 60 hari, setelah laporan hasil pemeriksaan diterima. Peraturan BPK Nomor 2 Tahun 2017 pada Pasal 4 mengatur bahwa jawaban atau penjelasan dan dokumen pendukung dalam rangka pelaksanaan tindak lanjut merupakan dokumen yang cukup, kompeten dan relevan serta telah diverifikasi oleh aparat pengawasan intern. Dengan belum selesai dan belum ditindaklanjutinya rekomendasi laporan hasil pemeriksaan (LHP) BPK itu maka terdapat permasalahan masih ada dokumen tindak lanjut yang belum atau tidak cukup, kompeten dan relevan, serta menimbulkan indikasi masih terdapat kelemahan dalam verifikasi dokumen tindak lanjut yang dilakukan oleh Inspektorat Daerah selaku aparat pengawasan intern. Sehingga ada fungsi kepatuhan yang belum berjalan atau terlaksana sepenuhnya sebagaimana mestinya.

Fungsi kedua yang terkait dengan pemeriksaan (auditing), dalam hal ini yang dilakukan oleh BPK Provinsi Jawa Tengah dalam melakukan pemeriksaan pengelolaan 
dan tanggung jawab keuangan daerah yang dilaksanakan oleh Pemerintah Kabupaten Wonosobo. Berdasarkan hasil observasi di lapangan diketahui bahwa Pemerintah Kabupaten Wonosobo mengelola keuangan daerah melalui Anggaran Pendapatan dan Belanja Daerah (APBD) melakukan pelayanan publik kepada masyarakat, antara lain diwujudkan dalam bentuk penyediaan sarana prasarana insfrastruktur (misalnya gedung, jalan, jembatan) maupun penyediaan barang dan jasa (misalnya pelayanan e-KTP, Kartu Keluarga) yang harus dipertanggungjawabkan dalam bentuk laporan keuangan pemerintah daerah setiap tahunnya. Laporan keuangan inilah yang dilakukan pemeriksaan oleh BPK setiap tahunnya memenuhi amanat peraturan perundangan, dengan membandingkan antara kriteria yang ditetapkan atau ketentuan atau aturan dibandingkan dengan kondisi senyatanya atau realisasi pelaksanaan APBD atau implementasi dalam melakukan pelayanan publik.

Fungsi ketiga terkait dengan akuntansi yang berhubungan dengan rekomendasi hasil pemeriksaan dapat memberikan gambaran informasi ke pada Bupati Wonosobo, selaku pembuat kebijakan, mengenai permasalahan apa saja yang terjadi dalam pengelolaan keuangan daerah, sehingga memberikan kepastian kepada Bupati Wonosobo dalam membuat kebijakan untuk melakukan tindakan perbaikan. Contohnya adalah terkait adanya temuan pemeriksaan BPK pada tahun 2017 mengenai pembayaran tunjangan kompensasi Cipta Kondisi Daerah untuk Tim Koordinasi Penyelenggara Pemerintahan membebani keuangan daerah sebesar 199 juta rupiah, maka berdasarkan rekomendasi BPK, mulai tahun 2018 dan untuk tahun-tahun selanjutnya Bupati Wonosobo menghentikan pemberian tunjangan tersebut dengan tidak menganggarkannya lagi dalam APBD Kabupaten Wonosobo. Dan setelah diteliti lebih lanjut, memang benar tunjangan kompensasi Cipta Kondisi Daerah sudah tidak dianggarkan lagi sejak bulan April 2018.

Fungsi keempat adalah eksplanasi, dapat dikatakan bahwa pemantauan tindak lanjut rekomendasi hasil pemeriksaan yang dilakukan oleh BPK dapat membantu Pemerintah Kabupaten Wonosobo dalam merancang program-program yang selaras dan seimbang dengan penetapatan kebijakan publik atau pengambilan keputusan untuk mengimplementasikan kebijakan dalam kerangka perbaikan tata kelola keuangan daerah yang lebih baik lagi, menjadi lebih akuntabel dan transparan sehingga dapat bermanfaat dalam memajukan dan mensejahterakan masyarakat Kabupaten Wonosobo. Dalam proses menindaklanjuti rekomendasi hasil pemeriksaan, pemerintah daerah mengevaluasi program dan kebijakan yang diimplementasikannya, untuk melakukan tindakan perbaikan yang sesuai dengan rekomendasi, sehingga temuan pemeriksaan yang telah terjadi dalam pengelolaan keuangan daerah tidak lagi menimbulkan patologi. Namun dalam implementasinya patologi dalam pengelolaan keuangan daerah masih terus terjadi.

Sehubungan dengan menghindari timbulnya patologi birokrasi dari Pemerintah Kabupaten Wonosobo sebagai akibat dari belum selesainya rekomendasi ditindaklanjuti, maka diperlukan adanya evaluasi kebijakan terkait dengan efektifitas pengambilan keputusan dalam menindaklanjuti rekomendasi hasil pemeriksaan tersebut. 
Apabila apabila upaya penyelesaian tindak lanjut hasil pemeriksaan untuk tujuan agar pengelolaan dan pertanggungjawaban keuangan daerah Kabupaten Wonosobo menjadi lebih akuntabel dan transparan, maka efektifitas tindak lanjut rekomendasi hasil pemeriksaan yang dilakukan oleh Pemerintah Kabupaten Wonosobo dapat dikatakan belum sepenuhnya efektif, karena permasalahan serupa yang masih terus terjadi dapat menjadi pertimbangan BPK dalam memberikan kualifikasi opini. Hasil penelitian ini juga sejalan dengan hasil penelitian (Tresnawati, 2016) bahwa tindak lanjut hasil pemeriksaan dapat memperbaiki kualitas laporan keuangan. Jadi semakin tinggi tindak lanjut hasil rekomendasi maka semakin baik kualitas laporan keuangan. Sehingga dapat diartikan sebaliknya juga bahwa semakin rendah tindak lanjut rekomendasi maka kualitas laporan keuangan juga menjadi tidak semakin baik. Dapat dilihat dari laporan hasil pemeriksaan atas SPI dari tahun 2013 sampai dengan 2017, jumlah temuan pemeriksaannya cenderung fluktuatif meningkat.

Namun seperti apa yang disampaikan oleh Bidang Akuntansi Evaluasi dan Pelaporan BPPKAD bahwa apabila upaya penyelesaian tindak lanjut hasil pemeriksaan keuangan daerah dengan tujuan perbaikan pengelolaan keuangan daerah Pemerintah Kabupaten Wonosobo supaya dapat meningkatkan opini laporan keuangan pemerintah daerah, maka tujuan yang diharapkan telah tercapai, yakni laporan keuangan daerah Kabupaten Wonosobo telah mendapatkan opini wajar tanpa pengecualian (WTP). Hasil penelitian ini sejalan dengan dengan hasil penelitian (Arianto et al., 2018) yaitu BPK akan terdorong untuk memberikan kualifikasi opini yang lebih baik atas kewajaran penyajian laporan keuangan pada tahun tersebut dengan adanya tindakan perbaikan yang memadai atas temuan permasalahan kelemahan SPI dan ketidakpatuhan terhadap peraturan perundang-undangan dalam hasil pemeriksaan BPK.

Salah satu pendekatan evaluasi yang dikemukakan oleh (Dunn, 2003) adalah evaluasi formal (formal evaluation) dengan salah satu tipenya adalah evaluasi formatif yang meliputi berbagai usaha untuk secara kontinu dan periodik memantau pencapaian tujuan dan target formal. Pemantauan pelaksanaan tindak lanjut rekomendasi hasil pemeriksaan oleh BPK pada Pemerintah Kabupaten Wonosobo dilakukan secara terus menerus setiap tahun dan periodik setiap semester sekali atau dalam setahun dilakukan 2 kali pemantauan, yakni setiap akhir semester I atau pada bulan Juni atau Juli dan akhir Semester II atau pada bulan Desember. Tujuan yang diharapkan dari kegiatan pemantauan tindak lanjut rekomendasi hasil pemeriksan ini adalah semua rekomendasi dapat ditindaklanjuti tanpa terkecuali, sehingga target formalnya adalah pengelolaan keuangan daerah dapat dilaksanakan tanpa adanya sutau permasalahan. Namun dalam implementasinya tujuan dan target formal yang diharapkan belum tercapai.

Tindak lanjut rekomendasi hasil pemeriksaan atas laporan keuangan Pemerintah Kabupaten Wonosobo, memenuhi permintaan BPK, telah didukung oleh adanya suatu rencana aksi (action plan) dari pemerintah daerah sebagai bentuk agenda setting untuk melakukan tindakan atau perbaikan sesuai rekomendasi hasil pemeriksaan, yang didalamnya telah termaktub perumusan kebijakan apa yang akan di ambil untuk diimplementasikan dalam kerangka perbaikan. Harapan dan tujuan dari Sekretaris 
Inspektorat dan Kepala Bidang Akuntansi Evaluasi dan Pelaporan BPPKAD untuk mempertahankan opini laporan keuangan supaya tetap WTP juga merupakan pendorong penyelesaian tindak lanjut hasil pemeriksaan. Sedangkan yang menghambat upaya penyelesaian tindak lanjut rekomendasi hasil pemeriksaan antara lain kuantitas pegawai atau staf di Sub Bagian Evaluasi dan Pelaporan Inspektorat masih kurang memadai dalam melaksanakan tugas pemantauan atas tindak lanjut rekomendasi yang dilakukan oleh OPD atau satuan kerja terperiksa. OPD atau satuan kerja kadangkala menyediakan data dan dokumen yang diminta oleh Inspektorat terkadang tidak sesuai dengan yang diharapkan dan ditentukan. Tingkat eselonitas Inspektur di Kabupaten Wonosobo ratarata setara dengan kepala OPD atau satuan kerja lainnya yaitu pejabat setingkat eselon 2, sehingga tidak mempunyai kewenangan yang cukup efektif dalam daya paksa dalam level yang setara. Perubahan Regulasi dan SOTK pada tahun 2015 dengan terbentuk dinas dan kantor baru dan unit kerja yang dihilangkan karena melebur dengan OPD lain di lingkungan Pemkab Wonosobo, maupun ditarik ke Pemprov Jateng, serta pergantian beberapa kepala OPD, bendahara pengeluaran, bendahara penerimaan, dan pengurus barang mengalami pergantian, yang kurang memahami core bussiness administrasi pelaksanaan tindak lanjut hasil pemeriksaan, cukup menghambat penyelesaian tindak lanjut rekomendasi hasil pemeriksaan tahun yang telah lama. Selain itu, pengurus barang OPD belum dibekali dengan sarpras memadai misalnya belum dibekali laptop/PC unit khusus, laptop/PC unit yang ada di dinas belum diinstal dengan Simda BMD secara online atau dilengkapi dengan kendaraan dinas untuk memantau aset tetap yang tersebar di wilayah Pemerintah Kabupaten Wonosobo sehingga menghambat penyelesaian tindak lanjut atas temuan aset tetap yang terus menjadi temuan BPK.

\section{Kesimpulan}

Pemerintah Kabupaten Wonosobo sudah berusaha dalam melaksanakan tindak lanjut atas rekomendasi hasil pemeriksaan atas pengelolaan dan tanggung jawab keuangan daerah seefektif mungkin. Hal ini ditunjukkan bahwa meskipun persentase penyelesaian tindak lanjut sebesar 71,97 \% yang merupakan terendah se Jawa Tengah, namun opini dalam pengelolaan keuangan daerah sudah memperoleh predikat wajar tanpa pengecualian (WTP) sejak tahun 2016. Hal ini dapat terjadi karena permasalahan yang timbul dan menjadi temuan Badan Pemeriksa Keuangan dibawah ambang batas toleransi dan tidak material serta tidak perpasif yang tidak mempengaruhi kewajaran penyajian laporan keuangan Pemerintah Kabupaten Wonosobo.

Sedangkan rekomendasi yang tidak segera ditindaklanjuti oleh Pemerintah Kabupaten Wonosobo berdampak pada ditemukannya permasalahan yang serupa dalam pemeriksaan BPK atas laporan keuangan pada tahun berikutnya. Permasalahan yang berulang kali ditemui oleh BPK adalah terkait dengan pengelolaan dan penatausahaan keuangan, aset tetap, persediaan dan piutang. Hal ini tentunya menunjukkan bahwa tindak lanjut yang dilakukan oleh Pemerintah Kabupaten Wonosobo belum sepenuhnya efektif dalam meningkatkan akuntabilitas pengelolaan dan pertanggungjawaban keuangan daerah. Masih adanya permasalahan serupa di tahun berikutnya meskipun 
rekomendasi atas hasil pemeriksaan sebelumnya telah selesai ditindaklanjuti, disebabkan oleh faktor: 1). Perbedaan OPD atau satuan kerja yang dijadikan sebagai sample pemeriksaan antara tahun lalu, tahun ini, dan tahun berikutnya. Sehingga apabila permasalahan di satu OPD rekomendasi perbaikan telah selesa dilaksanakan, maka OPD lain yang tidak menjadi sample pemeriksaan tidak diketahui apakah mempunyai permasalahan yang sama, belum tentu turut serta melaksanakan perbaikan yang direkomendasikan. 2). Perbedaan obyek pemeriksaan yang dilakukan oleh Badan Pemeriksa Keuangan meskipun di akun, fokus pemeriksaan, sasaran pemeriksaan dan OPD atau satuan kerja yang sama.

Pemerintah Kabupaten Wonosobo disarankan untuk meningkatkan persentase penyelesaian tindak lanjut atas rekomendasi hasil pemeriksaan atas pengelolaan dan tanggung jawab keuangan daerah sesuai dengan Peraturan Badan Pemeriksa Keuangan Nomor 2 Tahun 2017 tentang Pemantauan Pelaksanaan Tindak Lanjut Rekomendasi Hasil Pemeriksaan Badan Pemeriksa Keuangan. Langkah-langkah perbaikan dalam meningkatkan efektivitas tindak lanjut atas rekomendasi hasil pemeriksaan antara lain sebagai berikut: 1). Tersedianya kebijakan teknis terkait pelaksanaan tindak lanjut rekomendasi hasil pemeriksaan yang lengkap, jelas dan ringkas yang sesuai dengan kekhasan, kekhususan dan kearifan lokal daerah. Setelah itu mengkomunikasikan kebijakan penyelesaian tindak lanjut rekomendasi hasil pemeriksaan dengan lebih intensif kepada seluruh OPD di lingkungan Pemerintah Kabupaten Wonosobo. 2). Komunikasi dengan BPK ketika tim auditor BPK melakukan pemeriksaan dan menemukan permasalahan, mengenai jenis dan bentuk rekomendasi yang dapat dilaksanakan dalam tataran operasional, supaya rekomendasi dapat dilaksanakan dengan tepat sasaran, berdaya guna dan efektif. 3). Menyusun rencana aksi penyelesaian tindak lanjut rekomendasi hasil pemeriksaan dengan lebih memadai, sehingga pelaksanaan tindak lanjut rekomendasi hasil pemeriksaan dapat dijadikan sebagai awal mula dalam mengambil kebijakan pengelolaan keuangan daerah supaya lebih baik lagi. 4). Meningkatkan efektivitas monitoring dan evaluasi atas pelaksanaan tindak lanjut atas rekomendasi hasil pemeriksaan dengan mengedepankan faktor pendukung dan menciptakan solusi meminimalisir bahkan menghilangkan faktor penghambat penyelesaian tindak lanjut rekomendasi. 
Damas Ali Wijaya, Retno Sunu Astuti, Budi Puspo Priyadi

\section{BIBLIOGRAFI}

Anggara, Sahya. (2012). Ilmu Administrasi Negara: Kajian Konsep, Teori, dan Fakta Dalam Upaya Menciptakan Good Governance (Vol. 1). CV Pustaka Setia. Google Scholar

Arianto, Handoko, Heriyanto, Meyzi, \& Karneli, Okta. (2018). KSPI, KTPPU, TLRHP Dan Opini Bpk Atas Laporan Keuangan Pemerintah Daerah. JIANA (Jurnal Ilmu Administrasi Negara), 15(1), 13-22. Google Scholar

Cresswell, J. W. (2017). Research Design: Pendekatan Kualitatif, Kuantitatif, dan Mixed (Edisi Ketiga). Yogyakarta: Pustaka Belajar. Google Scholar

Dunn, William N. (2003). Pengantar analisis kebijakan publik. Google Scholar

Halim, Abdul, \& Bawono, Icuk Rangga. (2011). Pengelolaan Keuangan Negara-Daerah: Hukum, Kerugian Negara, dan Badan Pemeriksa Keuangan. Yogyakarta: Upp Stim Ykpn. Google Scholar

Howlett, Michael, \& Rayner, Jeremy. (1995). Do ideas matter? Policy network configurations and resistance to policy change in the Canadian forest sector. Canadian Public Administration, 38(3), 382-410. Google Scholar

Indonesia, Badan Pemeriksa Keuangan Republik. (2007). Peraturan Badan Pemeriksa Keuangan Republik Indonesia Nomor 1 Tahun 2017 tentang Standar Pemeriksaan Keuangan Negara. Google Scholar

Korje, Berhanu Gemule. (2016). Assessment of implementation of audit recommendations in public sectors in Oromia regional government public institutions (2003-2006 EC). The International Journal of Business \& Management, 4(2), 21. Google Scholar

Lusiana, L., Djamhuri, A., \& Prihatiningtias, Y. W. (2017). Analisis Penyelesaian Tindak Lanjut Hasil Pemeriksaan. Jurnal Economia, 13(2), 171. Google Scholar

Moleong, Lexy J. (2007). Metodologi Penelitian Kualitatif. Yogyakarta: Gadjah Mada University Press.

Purba, Charles Bohlen. (2014). Opini dan Status Tindak Lanjut Rekomendasi Badan Pemeriksa Keuangan pada Pemerintah Daerah di Kalimantan Barat, Tengah, dan Timur. Jurnal Akuntansi, 18(3), 383-407. Google Scholar

Raba, Mieke Rayu. (2017). Peran Badan Pemeriksa Keuangan (BPK) Dalam Melakukan Pemeriksaan Terhadap Pengelolaan Keuangan Negara Untuk Mewujudkan Pemerintahan Yang Baik Menurut UU No. 15 Tahun 2006. Lex Crimen, 6(3). Google Scholar

Singarimbun, Masri, \& Effendi, Sofian. (2019). Metode penelitian survai. Google 
Scholar

Tjandra, W. Riawan. (2006). Hukum Keuangan Negara, Jakarta: PT. Gramedia Widiasarana Indonesia. Google Scholar

Tresnawati, Fera. (2016). Pengaruh Tindak Lanjut Hasil Pemeriksaan Terhadap Kualitas Laporan Keuangan Dengan Tingkat Pengungkapan Laporan Keuangan Sebagai Variabel Moderating: Studi Empiris pada Kementerian/LembagaRepublik Indonesia. Universitas Pendidikan Indonesia. Google Scholar

\section{Copyright holder:}

Damas Ali Wijaya, Retno Sunu Astuti, Budi Puspo Priyadi (2022)

First publication right:

Syntax Literate: Jurnal Ilmiah Indonesia

This article is licensed under:

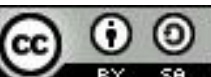

